\title{
Jim Corbett's My India: A Study of Ideological Otherness
}

\author{
Parul Rani ${ }^{1} \&$ Nagendra Kumar ${ }^{2}$ \\ ${ }^{1}$ Research Scholar in English in the Department of Humanities and Social Sciences, Indian Institute \\ of Technology (IIT) Roorkee, Roorkee-247667, Uttarakhand, India.Email Id: parulnet.e@gmail.com, \\ ORCID Id: oooo-0oo2-9934-3585 \\ ${ }^{2}$ Professor of English in the Department of Humanities and Social Sciences, Indian Institute of \\ Technology (IIT) Roorkee, Roorkee-247667, Uttarakhand, India. Email Id: naguk2o@gmail.com
}

\begin{abstract}
The present article draws on the ideological "othering" of the colonized subjects in Jim Corbett's story collection My India. The text assimilates the non-fictional stories of the Indian people at a time when Corbett operates as an influential colonial hunter, and as a fuel inspector in the different parts of the colonized India. By and large, the stories advocate the proximity between a colonial master (Corbett) and the colonized people (Indians). However, this paper argues these narratives fall into the space of colonial discourse where the erection and dismantling of the racial overtones are happening simultaneously. As a mode of representation, the repeated articulations: "the poor of India," "Indians are fatalists," and "superstitious" function a differencing category "other." The development of the discussion leads to the ironic reconstruction of caste through its subversion at the imperial hands. Precisely, this study probes into what Homi K. Bhabha says "mode of representation of otherness" $i$ and argues that Corbett's discourse loses to the ideological otherness against his experiential closeness to the Indians.
\end{abstract}

Keywords: colonial discourse, difference, Jim Corbett, My India, othering.

\section{Introduction}

Jim Corbett's My India (1952) is one of the celebrated colonial writings, making the colonized people the subject matter of its discourse. Differing from the other writings of Jim Corbett, this text focuses on the human characters with whom he comes in interaction during his stay in India. After Indian Independence in 1947, Corbett left India for Kenya, and his literary creation My India is written in Kenya. The detachment from the aesthetic fallacy and a plunge into his nostalgic state of the Kumaoni and Mokameh Ghat people offer a glimpse into the complexity of an exiled writer's psyche. ${ }^{\text {ii }}$ Although the possessing pronoun "My" assures Corbett's longing for the lost country, his letter to Hawkins in 1948 solidifies Corbett's imperialist attributes. It is the interests of the readers abroad that demand Corbett's knowledge of the poor of India:

I am writing the book in response to readers of Man-Eaters who have asked for more information about the poor of India. What I do mean is that I hope the people who were not interested in sport will be interested in the people of India. Not all the requests for a book on this subject have come from America; many have come from the UK, Canada, Australia, and from other parts of the world (Corbett, 2012, p. 51).

The memory of Corbett's seventy years in India enables the emission of multi-meanings. It makes a trajectory of British imperialism, Corbett and the rural folk of India. The study aims not to question Jim Corbett and his affinity with the Indians, but it clarifies the consistent uncertainty

(C) AesthetixMS 2020. This Open Access article is published under a Creative Commons Attribution Non-Commercial 4.0 International License (http://creativecommons.org/licenses/by-nc/4.0/), which permits non-commercial re-use, distribution, and reproduction in any medium, provided the original work is properly cited. For citation use the DOI. For commercial re-use, please contact editor@rupkatha.com. 
between his imperial self and (un)imperial bond with the natives. Outside academia, Corbett remains very popular as a great naturalist and wildlife conservationist, but academically his writings remain less explored and almost critically untouched in discussing his liabilities to the imperial enterprise.

This analysis of My India is through the postcolonial lens by using the concepts of "othering", "difference", and "the ambiguity of the colonial narratives." The occurrence of "othering" is through the articulation of the colonized subjects when the gap between the British and the Indians is regulated. iii The repeated expressions like "Indians are fatalists", "uneducated", "poor and deprived" and "untouchables" create an ideological disparity and design the colonized subjects other. ${ }^{\text {iv }}$ This othering is critical to analyze since it is shaping the colonial discourse when such others are uttered and asserted regularly. It is apt to recall Bhabha's definition of the colonial discourse: "[i]s an apparatus that turns on the recognition and disavowal of racial/cultural/historical differences. Its predominant strategic function is the creation of a space for a 'subject peoples' through the production of knowledges" (2015, p. 100). Adequately, the formation of knowledge builds the terrain of colonial discourse. With the execution of the knowledge of a social, cultural, historical and racial domain, the exercise of power complements to the formation of others. Lacan introduces a distinction between other and 'O'ther which is quite relevant to avoid the interchangeability of both the terms. ${ }^{v}$ Other is the signifier of power who dictates the othering by its discourse of difference and expelling it from the center, yet ironically constructing the Other; other comes to the center. "The construction of the dominant imperial Other occurs in the same process by which the colonial others come into being" (Bill Ashcroft et al., 2007, p. 156). Spivak systematically flourishes the notion of othering in the postcolonial theory where the Lacanian 'other' turns to be the colonized other. Moreover, this 'other' finds its placement in the colonial discourses through the implementation of differences from the powerful Other. In organizing the colonized others, belonging to different race and culture, the construction of an imperial Other is decorated with all the superior traits. In this course, the race (white) is a keynote speaker in the othering of a different race (brown/Hindu/Hindustani) with its peculiar features coming into discourse through colonial power and knowledge. ${ }^{\text {vi }}$ The exclusion of the colonized subjects from the center reversely remains an object of the imperialist dialogue.

The narratives register the mechanisms of the benevolent rule, fortitude hunting expeditions, and social services reconfiguring the colonial power that is warmly welcomed by the natives. It reminds of Foucault's notion of power which is capable of producing rather than destructing: "[ $t]$ hat traverses and produces things, it induces pleasure, forms knowledge, produces discourse" (Foucault, 1980, p. 119). The colonial formation of knowledge through power intertwines with other kinds of relations and perceptions, affecting the indigenous population through the acts of fortitude hunting expeditions, occasional help to the poor, unbiased judgment, close kinship with proletariats etc. This power entraps 'serving' the native land instead of ruling it, Corbett has referred several times in his narratives. Such kind of mechanism employed in a discourse generates "its 'general politics' of truth" (Foucault, 1980, p. 131) that functions to be true and associates with power in a circular form. ${ }^{\text {vii }}$ The linkage of colonial power with its productivity (economic production, social service, the native consent and obedience) is the construction of its regime of truth: "In order to understand the productivity of colonial power it is crucial to construct its regime of truth" (Bhabha, 2015, p. 96).

The characters of My India float on the British construction of knowledge. In the colonial environment, the proximity between Corbett and his labor at Mokameh Ghat fulfills the requirement of the colonized subjects in smooth functioning of colonial project of railways, along 
with the imperial rule as a favorable stance for the depressed class. The natives see gentleman persona in the colonial masters; and such relationships appear to "carry reciprocal duties like the relations between father and son (Maunier, 2002, p. 37).

Indeed, the idea of othering, concerning the colonizer and the colonized subjects is of the hierarchical relationship intersected with the roles of class, race, and gender. If put into Gingrich words: "Although the colonizing and the colonized are fundamentally different from each other, Spivak sees them as intrinsically linked to each other through reciprocal identity formation" (2006, p. 11), there is an installation of mutual inclusiveness of othering/difference and identity. The inbetweenness' of Corbett, as a British hunter and the native's sahib leaves the scope for tracing the stances of difference and othering in his narratives. It is through the critical analysis of the illustration of the natives that colors Corbett's identity as a White Master.

\section{Stances of Difference and othering}

The tales are multi-layered showing the socio-cultural ways of Indian rural folk, the methods of the colonial masters and the balance that both are making to co-exist. Corbett uncarefully marks the continuation of his White identity, culture, and western ways in protecting rural people from the wild animals or providing them the financial assistance or the moral support. The British Empire in India in its later phase is convoluted with the mechanisms of benevolence and paternalistic nurture. Pennycook throws the light on beyond the concept of 'bad colonials' renowned in India; if the tools of colonialism are required to be understood, one needs to blur the boundaries of strict and apparent tyrannical rule:

It is important to understand colonialism not only in terms of its macro political structures but also in terms of the cultural politics of everyday life . . . with respect to discussions of Macaulay and his famous Minute, this tendency to work with simplistic stereotypes has led to limited understandings both of colonialism and its relationship to the present (2002, p. 24).

Similarly, the episode of Sultana (a dacoit) provides an insight into the imperial responsibilities directed towards the natives. Freddy Young; a policeman takes the responsibility of Sultana's family after he receives death sentence: "Freddy adopted the dog, and those who know Freddy will not need to be told that he faithfully carried out his promise to care for Sultana's family" (Corbett, 2015, p. 131).

There is need to revise the politics employed in the day to day life that the native purely failed to understand. Corbett, being a hunter cum savior comes very close to the villagers of Kumaon during his hunting expeditions and eventually becomes a respected sahib. The concept of sahib needs the highlighting here as this is purely a signifier of hierarchy and involves the racial discrimination between the White and the Brown folk. All the narratives have one thing in common, i.e., the poverty of the Indian people. They are poor, uneducated, dependent, and subordinates to the Whites whether in hunting expeditions or at the railways at Mokameh Ghat. Dirks comments on such delineation: "Not only are the subjects ruled by the state; the position of the subjects are constituted by classifying and naturalizing such categories and identities as educated or uneducated, rich or poor, male or female, young or old, Hindu or Muslim, Welsh or Scottish, and so on" (1996, p. xi). Simultaneously, these people are honest, loyal, trustworthy and generous too. Their loyalty lies in to be faithful to their colonial masters. Corbett writes: 
Those who visit India for pleasure or profit never come in contact with the real Indian- the Indian whose loyalty and devotion alone made it possible for a handful of men to administer, for close on two hundred years, a vast subcontinent with its teeming millions. To impartial historians I will leave the task of recording whether or not that administration was beneficial to those to whom I have introduced you, the poor of my India (2015, p. 154).

"The real Indian" is caught in the criterion of interrogation? The distinction between real India and non-real Indian remains questionable. Are the real Indians only those simple folk who are voiceless against the colonial rule, and are assisting in the establishment of colonial empire? This articulation dissolute the native race in lauding the competency of the empire with 'serving' the colonized space in spite of 'administering' it, since it is the "White man's burden" to civilize the uncivilized in Rudyard Kipling's term. ${ }^{\text {viii }}$ It resembles Bhabha's proposition, "The objective of colonial discourse is to construe the colonized as a population of degenerate types on the basis of racial origin, in order to justify conquest and to establish systems of administration and instruction" (2015, p. 101). "Loyalty and devotion" are in fact the two essential components in the subjectification of the native population as they determine the textual duality because they are the support as well as the target itself. Through such support "process of subjectification" becomes feasible. ${ }^{\text {ix }}$ There is the acknowledgement of the difference in the form of "the poor of my India," where the writer is justifying the colonial rule over them as they are unlike the British. Said is also crucial in understanding such kinds of othering. He calls the Orientalist stage a "moral and epistemological rigor ... For the Orient ("out there" towards the East) is corrected, even penalized, for lying outside the boundaries of European society, "our" world; the Orient is thus Orientalized" (2001, p. 67).

The story "Pre-Red-Tape Days" glorifies the British Raj in India since it celebrates the affable rule of General Sir Henry Ramsay and Sir Frederick Anderson. They are extolled for the characteristics of stout and determined rulers, working for the 'simple uneducated people' in Terai (a lowland region in Northern India on the outer foothills of Himalayas); the place marked with malaria: "the scourge of Terai" (Corbett, 2015, p. 65). The aboriginal tribe of Terai is depicted through the imperial optics as the pre-eminence of the Whites is explicit in imparting a fair justice to all. These people are far from the hue and cry of the city who accept the British rule unquestionably:

The aboriginal tribe, living in the unhealthy Terai, is renowned for the two sterling qualities-cleanliness, and the independence of women . . . and in no other part of India would a young girl have dared, or in fact being permitted, to stand before a mixed gathering including two white men to plead her own cause (Corbett, 2015, p. 64).

Embedded with a sense of marginalization of the colonized country in general and Terai people in particular, the two issues tangle: the sexual/gender discrimination and the supremacy of the White race. The practice of hierarchical racial system attributes the power of decision making to the Whites, and ascribes the prestige of the natives in submissive locales. The acclaimed fidelity of the rural folk becomes the defining characteristic of the "real Indians." The contentment of the uneducated people, only in being remembered their names by the sahibs, explicit the imperial style of cultivating the colonial-colonized relationship. Sir Raymond West phrases such relationship: "The British rule in India has been specially distinguished from all previous governments by the inestimable blessings it has conferred in security, justice and material development" (qtd. in Pennycook, 2002, p. 48). Terai-ians respect Ramsay and Anderson for the sense of justice. Deconstructing this counterpart between White-ness and authority revives Fanon's assertion, "[y]ou are rich because you are white, you are white because you are rich" (2001, p. 31). Similarly, the question rises of the racial vantage that naturalizes the colonial power? Corbett writes: 
Both Ramsay and Anderson were Scotsmen, and it was said of them that once having heard a name or seen a face they never forget it. It is only those who have had dealings with simple uneducated people who can realize the value of a good memory, for nothing appeals so much to a humble man as the remembering of his name, or the circumstances in which he has previously been met" (2015, p. 61).

"Nothing appeals so much to a humble man as the remembering of his name" reveals the subjacent colonized mind-set, preoccupied with the Whites' position as something unattainable for them. This 'unattainability' creates the intellectual inferiority among the natives and assists in the process of subjectification. Stokes mentions in his lecture:

For imperialism was above all an unformulated philosophy of life and politics. At its heart was the belief that political power tended constantly to deposit itself in the hands of a natural aristocracy, that power so deposited was morally valid, that it was not to be tamely surrendered before the claims of abstract democratic ideals, but was to be asserted and exercised with justice and mercy (1960, p. 10).

Another uncertainty revolves around the writer himself in acknowledging and disallowing his colonial-self contemporaneously. Although very explicitly Corbett calls himself a White man, his experiential-self shrinks the boundaries between the two. The story "Mothi" entails the statement, "The poor of India are fatalists, and in addition have little stamina to fight disease. Deprived of our company, though not our help, Mothi lost hope when we left for our summer home, and died a month later" (2015, p. 45). Corbett seems to knit the racial strands as the character of Mothi evolves mentally and physically vulnerable in the absence of the White masters. The writer makes Mothi the persona of the poor Indians and their destitute stoicism. Further, the stories of "Lalaji" and "Chamari" secure the ambivalent homogenous expressions. The text reads, "We who live in India ... are fatalists, believing that a man cannot die before his allotted time" (2015, p. 162), and "We in India loathe and dread cholera but we are not frightened of infection, possibly because we are fatalists" (2015, p. 174). The pronoun 'we' brings ambiguity to the discourse and carries the disavowal of the racial differences. The identification between the colonizer and the colonized subject is occurring since Corbett is projecting himself as the part of the Indian community. Such is the underlying contradiction/ 'in-betweenness' of the narratives as Corbett employs the articulation of difference and sameness in continuity. The 'in-between' is derived from the Derridean concept of entre, or "between", the writer swings in-between of his imperial self and his experiential connectedness with the colonized others. ${ }^{x}$ Derridean entre is understood that, "[s]ows confusion between and stands between the oppositions at once" (Bhabha, 2015, p. 182). JanMohamed also throws light on such delineation:

Faced with an incomprehensible and multifaceted alterity, the European theoretically has the option of responding to the Other in terms of identity or difference. If he assumes that he and the Other are essentially identical, then he would tend to ignore the significant divergences and to judge the Other according to his own cultural values (2003, p. 18).

Attempts have been made to bring the sameness, but "not quite", ${ }^{x i}$ since the articulation of sahib is fundamental to Corbett's relationship with the Indian rural folk. The instances of the poor people coming to Corbett's house for the financial help, and the graphic description in the text manifest the gap between two races through certain dress codes, the way of sitting and addressing each other. The articulation, "On Sunday evenings Chamari and I would sit, he on a mat and I on a stool, with a great pile of copper pice between us" (2015, p. 170) discloses the existing political, cultural in addition to racial hierarchy, where Corbett is the administrator and Chamari, a worker. Lister detects this kind of othering as "[p]rocess of differentiation and demarcation, by which the 
line is drawn between 'us' and 'them'-between more and the less powerful-and through which social distance is established and maintained" (2004, p. 101). The White men hold the upper rank while the natives serve at the lower. The colonial masters become the sahibs of integrity, honesty, conscientious, and also the objects of imitation whom the colonized population wish to follow and act like them. Chamari's words to Corbett, "If you have been wearing that suit for years, and if you can do that, why can't I?" (2015, p. 172) Similarly, Corbett endorses the native people's enthusiasm for Christmas: "There are, however, one day in the year that all of us looked forward to with anticipation and great pleasure, and that was Christmas" (2015, p. 191). Having spent the life in the British Raj, the natives begin to see the world through the colonial gaze. Gingrich observes, "These are the 'others' that typically represent Spivak's colonial and postcolonial subjects, who only exists through, or against the powerful gaze of the colonial discourse" (2006, p. 11).

\section{Othering through Caste}

Colonialism embellishes the Indian society within the framework of 'caste' more explicitly. Dirks is among the very few who is perceptive on the coetaneous strengthening of casteism and imperialism in India. He considers caste:

[T] he product of an historical encounter between India and Western colonial rule ... I am suggesting that it was under the British that 'caste' became a single term capable of expressing, organizing and above all 'systematizing' India's diverse forms of social identity, community and organization (2001, p. 5).

Most of the characters in the text are introduced through their caste, and Corbett appears reconstructing the caste follies ironically. The utterance of caste unravels the coupled functions: first, it strengthens the Raj as it provides an equal platform for all community strata working together, as the narrative of "Chamari" exemplifies. Secondly, caste gets stability and becomes a symbol of Indian-ness. The Orientalist reconstructions of 'caste' serve the "cultural technologies of rule" (Dirks, 2001, p. 9) for the British Empire. The repeated emphasis on the caste attributed features of the characters like Mothi, Narwa, Haria, Chamari, Kunwar Singh, and others unveil the subject knowledge of the Indian caste system and its specific features. Corbett lays out, "Mothi had the delicate, finely chiselled features that are the heritage of all high-caste people in India" (2015, p. 33), similar is the narration of the old lady known as "queen of the village": "She is a Brahmin, the salt of India's earth ... Her dress is the same as worn by all high-caste hill women: a shawl, a tightfitting bodice of warm material, and a voluminous print skirt"xii (2015, p. 16).

Corbett solidifies his awareness of his European readers by emphasizing the caste idiosyncrasies (particularly of Untouchables) of the native society. "Narwa and Haria . . . had adopted the same profession, basket-making-which means that they were untouchables, for in the United Provinces baskets are only made by untouchables" (2015, p. 87). Also, the delineation of Chamari speaks the same, "Chamari, as his name implies, belonged to the lowest strata of India's sixty million Untouchables ... an angular person whose face was stamped with years of suffering . .. was an undersized man with a poor physique" (2015, p. 168). Caste basis hierarchical differences are the determinants of the native people's identity. It becomes a medium to understand and access the core of an Indian tradition.

Here, 'caste' breaks the boundaries of merely an articulation; instead, it is the understanding that the colonizers have developed into a mechanism to color the dark patches of a culture. The British Raj's attempts to subvert the caste abuses results in strengthening its rule. The story "Budhu" serves to illustrate this: the upper caste (bania) exploits him for the debt that his grandfather had 
taken years back. ${ }^{\text {iii }}$ Corbett makes him free by paying his debt that shows Corbett's warmth for his labor and imperialism as valuable for the depressed class. It results in such words by Budhu, "No, Sahib, no', he said. 'You must not burn these papers, for I am now your slave and, God willing, I will one day pay off my debt to you'" (2015, p. 160). Through the financial and medical assistance provided to Lalaji and other people, the imperialism functions as a nurturing and paternalistic statute for the 'simple uneducated people'. The colonial rule seems to be competent in questioning the caste hierarchies and challenges this tradition by appointing Chamari, the head of the coal gang:

In the gang he commanded there were men and women of all the castes including Brahmins, Chattris, and Thakurs, and never once did he offend by rendering less respect to these highcaste men and women than was theirs by birthright, and never once was his authority questioned (2015, p. 169).

Alike, equal access is provided to the students of high caste and low caste in Ram Saran's school pleasing the colonized people consequently. Raheja has termed such discourse of caste ideology, " $[t] o$ create the illusion that the disciplinary control of the specific castes and of the Indian population as a whole was carried out with the consent of the colonized" (1996, p. 494). The discourse of caste justifies the patronizing colonial rule. Dirks comments: "[U]nder colonialism (caste) was anchored to the service of a colonial interest in maintaining social order, justifying colonial power, and sustaining a very particular form of indirect rule" and further, asserts that indirect rule is manifested through the mechanisms of "buttress and to displace colonial authority" (2001, p. 15). The narratives give an expression of the close contiguity between Corbett and Indian people; the incident of taking meals at the headman's home serves a fine example:

After a very generous and very welcome meal - for I had eaten nothing that day-I picked up the plates with the intention of washing them in a nearby spring. Seeing my intention the three girls ran forward and relieved me of my plates, saying, with a toss of their hands and laugh, that it would not break their caste-they were Brahmins - to wash the plates from which the White Sadhu had eaten (2015, p. 15).

It represents the prominence of casteism and the consent of the colonized others in welcoming a White master. Caste substantiates the thematic structure of the tales since almost all the characters, Corbett has chosen from the depressed class. Corbett, inseparable from British colonial administration, improbably stands as a purely benevolent character for the colonized folk. His narratives depart from the conventional opposition between the two poles: colonial and colonized but express a sound touch of cultural otherness. He is a prime figure of displacing forceful colonial authority but undoubtedly remains a dominant imperialist pole, supporting the British Empire. In analyzing an ambiguous position, it is illuminating to remind Bhabha's words, "The analytic of ambivalence questions dogmatic and moralistic positions on the meaning of oppression and discrimination" (2015, p. 95). Corbett's narratives' voices linger the suspension of discrimination by maintaining it camouflaged(ly). The representation of the caste as an integral part of the native society is, in fact, the portrayal of the other culture that is full of depravity, disease, superstitions, and poverty. Although there are several references to the Untouchables, the narratives blur these differences and show the unity of the Indian community. The casteism becomes a tool to access the simple folk, understanding them, and certainly reigning over them unadversely, Bayly comments on the British Raj in India making the caste system very rigid as it is, "a central mechanism of administration" (1999, p. 392). In spite of the synergy with the poor of India, the colonial decorum and dignity with a high-caliber fertilize the text. There is a paradoxical articulation: first, the caste conveys the dividing element of the colonized society but simultaneously the characters like the herdsman, a Brahmin in "The Law of the Jungles" appears to bypass the various forms of division 
and Untouchability. Corbett says at the end, "My men and I served India at a time when the interest of one was the interest of all, and when Hindu, Mohammedan, Depressed class, and Christian could live, work and play together in perfect harmony . . . for the poor of India have no enmity against each-other" (2015, p. 192). Secondly, these simple men are as honest as is Lalaji who never forgets to repay the respect but synchronously; there is a sense of difference when these people stand with their peculiar beliefs, faiths, and weaknesses regarding the diseases and other manners as well. Corbett's statement "I never inquired into the private affairs of my workpeople, for Indians are sensitive on this point" (2015, p. 157), corresponds to a White man's point of view with a detachment, while the narratives reciprocally communicate the interest of the Indians in sharing their difficulties/pleasures with Corbett. The text depicts the native land as a land of diseases: malaria and cholera and many people dying with it including Sher Singh, Parbatti, and Chamari. He says, "Cholera is dreadful throughout the land, and when it comes in epidemic form as many die of stark fear as die of the actual disease" (2015, p. 162). Similar is the view of Metcalf: "[T] he British conceived of India as a land of dirt, disease, and sudden death" (2008, p. 171).

\section{Conclusion}

As discussed in this article, My India imprints the complexity of imperial enterprise and Corbett's nostalgic remembrance of the poor of India. The analysis brings together: the White and Brown identities of the writer in portraying the rural folk of India as he is holding both in continuity. The text creates a flux of 'sameness and otherness,' and the argument peeks into the 'contested-self' of the author. ${ }^{\text {xiv }}$ There are constant recognition, and disavowal of difference comprising the colonized subjects; it is a discourse that activates colonial power and knowledge over the indigenous folk. The experiences of the native land make it feasible for the author to portray the native disciplines in specific ways. However, the discourse brings ambiguity in between the lines of the text when the articulation works double. The colonial rule is the justification for the poor of India since they are imprudent and economically deprived. But they are the same colonized subjects that make the colonial rule a success, as they need it and actively participate in their subjectification by accepting their inadequacy. Although they are honest and diligent, are lacking in leadership. At the same time, the inquiry into the text finds the mechanisms of colonial rule in the form of knowledge, benevolence, and superiority of the White race attributing power to the colonial masters and consequently they remain untroubled and unquestioned imperial identity among the poor of India. The dynamics of the relationship between colonizer and colonized resurrects Sartre's words, "A relentless reciprocity binds the colonizer to the colonized" (2003, p. 4).

\section{Notes}

i Bhabha's reading of the colonial discourse is mainly concerned with questioning the otherness which has been articulated in different modes, rejecting the traditional ways of employing specific differences, in the colonial texts. This phrase accentuates the deconstructing of the text and questions the articulation of differences, entangled ambivalently. See The Location of Culture, p. 97.

ii Kumaon region/Kumaon Province in North India was a 'non-regulated' mountainous province of the British Raj. See Martin.

Mokameh Ghat was an essential and connecting trading/transporting railway link in eastern India. It was in the Danapur division of the East Central Railway Zone, where Corbett worked as a fuel inspector.

iii "othering" is a process in which the colonized become the signifiers of others in the construction of the European self. G. C. Spivak flourished othering as a concept fully in "The Rani of Sirmur: An Essay in Reading 
the Archives" (1985). This process takes place in several ways: race, class and gender. In this essay, I have used the concept of "othering" in analyzing a discourse about the simple rural folk of India who is geographically and socially distanced from the mainstream. It is to explore the contested nature of Jim Corbett's narrative where he is entangled in his white/brown identity, and consciously/unconsciously the racialized othering opens up prominently in the text. It is serving the dual purposes as Riggins says, "othering tells more about those who do the othering than those who are being othered" (10).

iv See Corbett $(162,61,154,45,87)$.

'The use of Lacan's distinction between Other and other emphasises its relevance in the postcolonial thought by making a difference between imperial Other and colonized other. See Bill Ashcroft et al., p. 156.

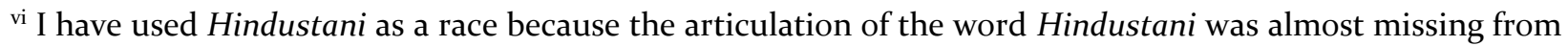
the literature till the Europeans used it to designate a race. Kant divides the human beings into four races, "I believe that we only need to assume four races in order to be able to derive all of the enduring distinctions immediately recognizable within the human genus. They are: (1) the white race; (2) the Negro race; (3) the Hun race (Mongol or Kalmuck); and (4) The Hindu or Hindustani race" (11).

vii The mechanism of serving the native country is explained through the production of truth when it plays in the hands of power, seen by lenses of Foucault's "'general politics' of truth" (131).

viii This title revives the responsibility of the civilised white race to educate/civilise the non-white race.

ix See Bhabha, (p. 103) to go beyond the conventional ways of reading a text (mainly colonial) as embedded with oppression and discrimination and to trace the welcoming ways of the colonized people's own subjectification.

x The explanation of the French word entre has been taken as 'between'. See Hobson, p. 85.

${ }^{x i}$ Initially, the term takes place in order to show the colonial mimicry when the colonized other is in the process to be recognized as a reformed Other. Although it is subjected to the difference, superficially appears the same but not entirely because the innate difference persists. See. Bhabha, p. 122.

xii Brahmin is an upper caste in India, maintaining its refined culture and features and plays a dominant and respectable role in Indian society. See Ambedkar (1917), and Risley (1999). Risley described the racial basis of Indian culture, particularly interested in the classification of people based on their language, dress, colour, physical characteristics, behaviour etc. (I am using this caste description particularly in context to the preindependence era).

xiii Bania in Indian society is known as a businessman involved in money lending, shop keeping, and trading. See Blunt.

xiv The notion of sameness and otherness asserts the dubiety of the text. As the colonized subjects are fully knowable and accessible yet remain other. And at times, through the delineation of the same colonized subjects, the otherness is being put at stake by the writer.

\section{References}

Ambedkar, B. R. (1917). Castes in India: Their Mechanism, Genesis and Development.Indian Antiquary, XLI. Retrieved 27 July, 2017, from $\leq$ www.columbia.edu/itc/mealac/pritchett/ooambedkar/txt ambedkar castes.html $>$.

Ashcroft, B.et al. (2007). Post-colonial Studies: the Key Concepts. $2^{\text {nd }}$ ed., Taylor and Francis elibrary.

Bayly, S. (2008). The New Cambridge History of India: Caste, Society and Politics in India from the Eighteenth Century to the Modern age [vol. 4 (3)]. Cambridge Histories Online: Cambridge University Press. Retrieved 24 November, 2017, from <http://b-ok.org/book/818353/4de437>.

Bhabha, H. K. (2015). The Location of Culture. Haryana: Replica Press (Third Indian Reprint).

Blunt, E. (1969). The Caste System of Northern India. Delhi: S. Chand \& Co. Retrieved 13 January, 2017, from <www.archive.org/details/in.ernet.dli.2015.187247/page/no $>$.

Cohn, B. S. (1996). Colonialism and its Forms of Knowledge: The British in India. 
Princeton: Princeton University Press.

Corbett, J. (2012). My Kumaon: Uncollected Writings. New Delhi: Oxford University Press.

Corbett, J. (2015). The Second Jim Corbett Omnibus: My India, Jungle Lore, Tree Tops $\left(33^{\text {rd }}\right.$ imp). New Delhi: Oxford University Press. (My India was first published in 1952).

Dirks, N. B. (1996). Foreword. In Bernard S. Cohn, Colonialism and its Forms of KnowledgeThe British in India (pp. ix-xvii). Princeton: PrincetonUniversity Press.

Dirks, N. B. (2001). Castes of Mind: Colonialism and the Making of Modern India. Princeton: Princeton University Press.

Fanon, F. (2001). The Wretched of the Earth. Constance Farrington (trans.). Gurugram: Penguin Classics. (first published in 1965).

Foucault, M. (1980). Power/Knowledge: Selected Interviews and Other Writings 19721977. Colin Gordon (Ed.). Colin Gordon, et al. (trans.).

UK: The Harvester Press.

Gingrich, A. (2006). Conceptualising Identities: Anthropological Alternatives to Essentialising Difference and Moralizing about Othering. In Gerd Baumann and André Gingrich (Eds.), Grammmars of Identity/Alterity - A Structural Approach (pp. 3-17). New York, Oxford: Berghahn Books.

Hobson, M. (2001). Jacques Derrida: Opening Lines. Taylor and Francis e-Library. Retrieved 30 December, 2017, from $<$ http://dlx.bok.org/genesis/49400o/bd21eaa1aa517f988ab6b694f73d1905/ as/[Dr Marian Hobson, Marian Hob son] Jacques Derrida(b-ok.org).pdf >.

Janmohamed, A. R. (2003). The Economy of Manichean Allegory. In Bill Ashcroft, et al. (Eds.), The Post-Colonial Studies Reader (pp. 18-23). Taylor \& Francis e-library. Google Books.

Kant, I. (2000). Of the Different Human Races. In Robert Bernasconi and Tommy Lee Lott (Eds.), The Idea of Race (pp. 8-22). Indianapolis: Hackett Publishing.

Kipling, R. (1998). The White Man's Burden. Peace Review, 10 (3), pp. 311-312. DOI: 10.1080/10402659808426162.

Lister, R. (2004). Poverty. Cambridge: Polity Press.

Martin, R. M. (1837). History of the Possessions of the Honourable East India Company, Vol. I. London: Whittaker \& Co. Google Books.

Maunier, R. (2002). The Sociology of the Colonies [Part 1]: An Introduction to the Study of Race Contact. Oxon: Routledge. Google Books.

Metcalf, T. R. (2008). The New Cambridge History of India: Ideologies of the Raj, Vol. 3 (4). Cambridge Histories Online: Cambridge University Press. Retrieved 13 January, 2017, from <www.bookzz.org/ireader/887601 $>$.

Pennycook, A. (2002). English and the Discourses of Colonialism. Taylor and Francis e-Library. Retrieved 30 August, 2016, from <www.bookzz.org/ireader/689268>.

Raheja, G. G. (1996). Caste, Colonialism, and the Speech of the Colonized: Entextualization and Disciplinary Control in India. American Ethnologist, 23 (3), 494-513. Retrieved from <www.jstor.org/stable/646349>.

Riggins, S. H. (1997). The Rhetoric of Othering. In Riggins (Ed.), The Language and Politics of Exclusion - Others in Discourse (pp. 1-30). Sage Publications.

Risley, H. H. (1999). The People of India (2 ${ }^{\text {nd }}$ ed.). William Crooke (Ed.). New Delhi: Asian Educational Services.

Sartre, J. P. (2003). Introduction. In Albert Memmi, The Colonizer and the Colonized (pp. 1725). London: Earthscan Publications Ltd..

Said, E. W. (2001). Orientalism. India: Penguin Books. (first published in 1978).

Spivak, G. C. (1985). The Rani of Sirmur: An Essay in Reading the Archives. History and Theory, 24 (3), 247-272. Retrieved from <www.jstor.org/stable/2505169>.

Stokes, E. (1960). The Political Ideas of English Imperialism: An Inaugural Lecture. College of Rhodesia and Nyasaland: Oxford University Press. 